\title{
Access to Prison Law Libraries as a Precursor to Effective Administration of Justice in Nigeria: Lessons from the United States of America
}

Oludayo John BamgBose ${ }^{1}$

\section{INTRODUCTION}

To ignore the reformation of inmates is to jeopardize our collective safety and security and compromise our national well-being and safety. That, for example, there are over 4,000 inmates in the Kirikiri Medium Prison. That is well above its 1,700 built-up capacity; and many of them, over 70 per cent are awaiting trial inmates!

Benson Iwegwu, $2017^{2}$

A decade after the inauguration of the national working group on the reform of criminal justice administration in Nigeria by the then Attorney General of the Federation, Chief Akin Olujinmi, SAN, ${ }^{3}$ Nigeria was presented with a newly signed law-Administration of Criminal Justice Act (ACJA), which was a direct response to the growing call for reforms that would address the plethora of problems ${ }^{4}$ confronting the administration of the criminal justice system in Nigeria. ${ }^{5}$ The 495 -section law ${ }^{6}$ harmonized the existing two principal laws: the Criminal Procedure Act (CPA) and the Criminal Procedure Code (CPC), which hitherto governed the administration of criminal justice system across all Federal-owned Courts in Nigeria and the Courts within the Federal Capital Territory. ${ }^{7}$ Both CPA and CPC operated for many decades in Nigeria, but had many challenges, ${ }^{8}$ hence the urgency for the newcomer- ACJA.

The newly enacted ACJA, which is now to operate in all Federal Government-owned Courts in Nigeria, seeks to give prompt attention to impediments to speedy and efficient administration of the criminal justice system in Nigeria. This has been captured succinctly by a learned law professor, who concluded that the Act has been put in place:

${ }^{1}$ C John Oludayo Bamgbose, 2018. The author is Certified Librarian of Nigeria (CLN), a Barrister and Solicitor, Supreme Court of Nigeria and Law Librarian, Ajayi Crowther University, Oyo, Nigeria. He was awarded the Bitner Research Fellowship for 2017 Fall, during which time this research was initiated. The author is grateful to the authorities of Cornell Law Library, Cornell University, Ithaca, United States for awarding him the Bitner Research Fellowship, which enabled him to undertake this study while at Cornell. The Law Library also facilitated appointments with relevant individuals and organizations useful for this study.

${ }^{2}$ Iweguw, Benson (2017) The revolution in Nigerian prisons, THIS DAY newspaper. September 8, 2017. Retrieved November 24, 2017 from https://www.thisdaylive.com/index.php/2017/09/08/the-revolution-in-nigeria-prisons/.

3 Akinseye-George, Y. (2015) Innovative provisions of Administration of Criminal Justice Act 2015, The Nations Newspaper, June 9, 2015 from http://thenationonlineng.net/innovative-provisions-of-administration-of-criminal-justice-act2015/.

${ }^{4}$ These problems were identified by Civil Society Organizations (CSOs) as well as interest groups like the Nigerian Bar Association (NBA), and International Organizations including the United Nations (UN) and Amnesty International (AI), amongst other organizations that all advocated for an improved system that would truly dispense justice.

5 Akinseye-George, Y. (2015) Innovative provisions of Administration of Criminal Justice Act 2015, The Nations Newspaper, retrieved June 9, 2015 from http://thenationonlineng.net/innovative-provisions-of-administration-of-criminaljustice-act-2015/.

${ }^{6}$ Administration of Criminal Justice Act, 2015.

${ }^{7}$ Administration of Criminal Justice Act, 2015.

${ }^{8}$ Ibid. 
to promote efficient management of criminal justice institutions and speedy dispensation of justice, protect the society from crime, and Protect the rights and the interest of the defendant and the victim. ${ }^{9}$

While the enactment of ACJA is one step in the right direction, some critics ${ }^{10}$ are of the view that efforts should be made to encourage the entire thirty-six states ${ }^{11}$ in Nigeria to include the Act in their own state level laws, particularly if it would benefit the nation as a whole. This is because state-controlled Courts are not bound by the provisions of the new Act. ${ }^{12}$ In addressing the challenges, ACJA's focus is on three cardinal pillars involved in the administration of justice: the police, the courts, and the prisons, as direct and positive relationships exist amongst the three arms. For example, a defective policing system is likely to occasion miscarriages of justice, while an inefficient Court system is unlikely to dispense justice. A prison system that is poorly managed has the tendency to be a fertile ground for breeding advanced crimes. ${ }^{13}$ The focus of this research is to examine the prison system and to narrow this down to prison libraries.

\section{Prison Reforms}

The prison system as a pillar in the administration of justice is essential towards any successful criminal justice system. On a general note, the retributionists' and the deterrent philosophers' opinion is that persons who have engaged in one form of crime or the other should be punished in a manner commensurate with the offense that has been committed, thereby serving as a deterrent to others who may contemplate committing the same crime or omission. ${ }^{14}$ As a result, these individuals when apprehended are isolated in confinement ${ }^{15}$ to ensure that they do not communicate with the outside world, either during trial ${ }^{16}$ or upon conviction. Currently, particularly in more developed countries, the role of prison is gradually changing from an isolated facility where the incarcerated are kept either during trial or upon conviction. Now perceived as complementary centers, the prisons provide wide-ranging services, including, but not limited to, reformation, rehabilitation, and re-integration back into larger society. ${ }^{17}$ In the Nigerian case, this modern philosophy appears to be more of an ambition rather than the reality. It was reported that:

more than half of all prisoners are reconvicted of a crime within a year of being

released. The evidence shows that education and employment are critical in

reducing reoffending and therefore cutting crime-yet around one in a hundred

prisoners enters employment on their release. Worryingly, just one in ten leaves

prison with an education or skill ${ }^{18}$

${ }^{9}$ Ibid Akinseye-George, Y. (2015).

${ }^{10}$ Onyekwere, J. and Dunia, G. (2015) Administration of Criminal Justice Act and Burden of Implementation, GUARDIAN newspaper, Retrieved June 9, 2015 from http://www.ngrguardiannews.com/2015/07/administration-of-criminaljustice-act-and-burden-of-implementation/.

${ }^{11}$ Out of the thirty-six states in Nigeria, only three states of Lagos, Anambra, and Ekiti have their state equivalent of the Administration of Criminal Justice Act.

${ }^{12}$ Nigeria operates a federal system of government,which vests the empowers to legislate on State Courts on the State Houses of Assemblies.

${ }^{13}$ This is one of the reasons prison breaks occur. It simply shows that the prison in need of reform has actually turned into a place where evil ideas are nurtured.

${ }^{14}$ Obioha, E. E. (2011). "Challenges and reforms in the Nigerian Prisons System.” Journal of Social Science, 27(2), 95109.

${ }^{15}$ Depending on the gravity of the offense perceived to have been committed.

${ }^{16}$ For certain categories of offense such as the offenses that could attract capital punishment, suspects undergoing trials are kept in prison pending the case being brought before the court. This is born out of the belief that a person so accused might indeed be guilty of the offense and if so, such a person may pose a greater risk to society if allowed to go and move freely.

${ }^{17}$ Adeagbo, O. et al. (2016) "Re-integration of prison inmates in Nigeria: advocating for library support," International Information and Library Review, vol., 48, no. 3: 169-73.

${ }^{18}$ Fapohunda, O. (2016) "Nigerian Prison Services: Practical Proposals For Reform,” THIS DAY, July 19, 2016.

https://www.thisdaylive.com/index.php/2016/07/19/nigerian-prisons-services-practical-proposals-for-reform/. 
This is understandable, considering that Nigerian prisons are over-stretched and lacking basic facilities. ${ }^{19}$ There are attempts to decongest the Nigerian prisons, including alternative sentences like community service, parole, and suspended sentences. ${ }^{20}$ And there is also amnesty. ${ }^{21}$ In as much as some these initiatives will be helpful, the reforms must be holistic. ${ }^{22}$

It is essential to Fapounda's view that there is a need to go back to the drawing board to examine the very essence of establishing prisons in Nigeria. It is equally suggestive of the need to focus more on adding value to time spent incarcerated, including education, empowerment, and above all, complete re-orientation of both the staff of the prison service and the inmates. Simply put, a punitive structure, which isolates prisoners with the intention of meting out punishments, ${ }^{23}$ will no longer produce the desired results in current society.

It is our contention that the provision of well-funded and properly managed prison libraries across the Nigerian prison system can complement the efforts of the government in effecting a change of the status quo. This will present a subtle approach to overhauling the entire prison system.

\section{Components of an Ideal Prison Library}

For this study, we are limited to the areas within which information can be provided to:

\section{- Enforcement of personal right to liberty}

Information concerning enforcement of fundamental rights should be provided for inmates, particularly for those on appeal and persons awaiting trial. In the United States, inmates are not only provided with information, they are also provided with documentation that will be presented in Court during their hearing. ${ }^{24}$

\section{- Personal development}

The time in prison ought to be a time for true reflection and resolve for personal development. It is recommended that information-bearing materials on entrepreneurships and other areas of proficiency, such as the mastery of employment skills and learning of languages, be provided, particularly for younger inmates and those who have significant time to spend behind bars.

\section{- Religious information}

Religious teachings are very important for teaching morals and for deterring anti-social or delinquent behaviors. Often, a number of inmates released through the prerogative of mercy are usually religious persons who have shown remorse and a change of attitude. Also, inmates believe that they could find favor before the authorities and be discharged before their time if God chooses to intervene in their affairs. ${ }^{25}$ Even the International

${ }^{19}$ Porthacourt Prisons, with a capacity of 804, accommodate more than 3,593 inmates; the Agodi Prisons, with a capacity of 294, now house over 1,000 inmates; Owerri Prisons, which should accommodate a maximum of 548, have over 2,144 inmates. The Ikoyi Prisons, with a capacity of 800, hold over 2,239 inmates. See Fapounda, W. (2017), 2017 Administration of Justice Reform Options for Buhari Government. THIS DAY newspaper, January 3, 2017. https://www.thisdaylive.com/index.php/ 2017/01/03/2017-administration-of-justice-reform-policy-options-for-buhari-government/.

${ }^{20}$ Akinseye-George (2015), ibid.

${ }^{21}$ Governors and some qualified judicial officers often in exercise their constitutional power and grant pardon to deserving inmates. However, there is a limit to the number of inmates who can be released under this arrangement because of the stringent conditions that have to be met. Regrettably, some Nigerians have attributed the over-crowded nature of the prisons to non-execution of inmates, thereby calling that Nigeria should return to the era of execution. Such a call is not in keeping with the global call against the abolition of the death penalty and we strongly condemn such a proposition.

${ }^{22}$ Where over 70 percent of inmates are persons awaiting trial, this then goes against the argument that prisons are overcrowded as a result of the refusal of the government to execute inmates. There is no amount of amnesty that can be given that will significantly affect the over-crowded nature of the prisons. The government would do better to explore ways in which there can be speedy administration of justice.

${ }^{23}$ Besides isolation, inmates are perhaps the most abused in Nigeria. For example, they are not eligible to vote in an election.

${ }^{24}$ The prison libraries hold papers that will be provided in court so that inmates who face similar charges can prepare his/her own documents for self-defense.

25 There is a story in the Bible where two men, named Paul and Silas, incarcerated by the King, were full of praises to God and in an unexplainable manner, they were released through the supernatural power of God. 
Federation of Library Association (IFLA) has alluded to the role of religious information in meeting the information needs of the inmates. ${ }^{26}$

\section{- Biographies/autobiographies}

It is of great importance that biographies and autobiographies of upstanding and inspirational people are provided for inmates. Such literature has a way of influencing the minds of readers. Therefore, stories of persons who have been in prison and who have become better persons can be truly encouraging. Nelson Mandela's autobiography is a classic example of an individual who, though he suffered through imprisonment, became an inspirational leader. ${ }^{27}$

\section{- Staying out of trouble}

While it is not in all instances that inmates have actually committed the crime for which they are being punished, ${ }^{28}$ on most occasions, inmates actually are guilty and, as a result, require help on how to stay out of trouble. Carefully chosen literature on psychology and sociology can be very useful in these cases.

\section{- Overcoming addictive behaviours}

The genesis of crime can on many occasions be traced to addictive behavior, such as dependence on drugs or alcohol, and other addictive behaviors. ${ }^{29}$ Where such persons complete their assigned jail time, but have not overcome their addiction, such a person is much more likely to return to a life of addiction when back in society.

\section{- Preparation for life after prison}

Prisoners often experience stigmatization when released from prison in Nigeria. ${ }^{30}$ Unlike the United States of America, where an ex-convict could be appointed a Professor of Law, ${ }^{31}$ it is unlikely that such a thing would happen in Nigeria. As a matter of fact, the mere idea that a legal practitioner has been found guilty and jailed is sufficient for such a legal practitioner to have his name struck off.

\section{- Advancement of education}

The prison term offers the opportunity for people to advance in terms of education. Therefore, access to educational materials could encourage and assist inmates to enrol in academic degree programs such as those offered by the National Open University of Nigeria (NOUN). ${ }^{32}$

\section{Nigerian Prison Library}

The importance of library services to prisoners has been widely canvassed. Besides information being considered as a fundamental right, ${ }^{33}$ its provision for the incarcerated is the key to rehabilitation and reformation of inmates, who upon release will better integrate into society. ${ }^{34}$ This outcome is also aligned with the intentions of establishing prisons in the first place. ${ }^{35}$ In this case, the United Nations has recommended "every institution shall

\footnotetext{
${ }^{26}$ Lehmann, V. \& Locke, J. (2005) Guidelines for library services to prisoners, 3rd ed., International Federation of Library Associations IFLA professional reports No. 92.

${ }^{27}$ Mandela's story is not only inspiring, but also preaches forgiveness for those who felt they needed to revenge wrongful conviction, not fearing the likely consequences of such retaliation.

${ }^{28}$ Nelson Mandela's jail term buttresses this claim. In Nigeria also, this is true of many of the activities of those such as the late Gani Fawehinmi, Fella Anikulapo Kiti, Chief Olusegun Obasanjo, and many others who have been jailed, in particular during the military dictatorship.

${ }^{29}$ Such behaviors include kleptomania, abusive relationships, and so on.

30 Many of inmates are discriminated against when released from prison such that life after prison becomes intolerable.

${ }^{31} \mathrm{Kroft}$, S. (2017) "Meet a convicted felon who became a became a Georgetown law professor." Retrieved October 15, 2017 from https://www.cbsnews.com/news/meet-a-convicted-felon-who-became-a-georgetown-law-professor/.

${ }^{32}$ Falayi, K. (2015) "Inspiring tales of life prisoners piling up degrees." Punch. August 29, 2015. Retrieved from http:// punchng.com/\%C2\%ACinspiring-tales-of-life-prisoners-piling-up-degrees/.

33 Eze, J. (2014) "Information needs of prisoners in Southeast Nigerian prisons," Sage, vol. 32 no 3: $243-53$.

34 Okwor, R. N. et al. ( 2010) "Library services to prisoners in south east geopolitical zones in Nigeria," Samaru Journal of Information Studies, vol. 7, no.1 ( 2010); vol.64, no. 4.

${ }^{35}$ Fapohunda, O. (2016), ibid.
} 
have a library for the use of all categories of prisoners, adequately stocked with both recreational and instructional books, and prisoners shall be encouraged to make full use of it." 36

The 1994 Charter for the Readers ${ }^{37}$ ascribed reading as a universal right, while the IFLA/UNESCO Public Library Manifesto (1995) beckoned public libraries to extend their services to prisoners. Part of the State's obligation is the provision of education services to its citizens ${ }^{38}$ regardless of the status of the citizens. ${ }^{39}$ The Nigerian Government, in light of this recommendation, has made provision of space for libraries in many prisons in Nigeria. However, there seems to be no other meaningful commitment on the part of the Government besides the designated space for the library. ${ }^{40}$ Worse still, the collections in these poorlymanaged prison 'libraries' are managed by persons who do not have training in the management of information resources. ${ }^{41}$ The level of impact of such a haphazard system of information management needs not be further described. ${ }^{42}$ In all of these cases, one thing is sure and regrettable: the management system of Nigerian prison libraries clearly conflicts with the conditions enumerated on the condition of services to inmates as provided for by the United Nations in its Standard Minimum Rules for the Treatment of Prisoners. ${ }^{43}$ At the moment, regrettably, about 75 percent of the information needs of inmates are met through religious bodies in the prison, while only about 11 percent of inmate information needs ${ }^{44}$ are met through the services of the library. ${ }^{45}$ While the situation is sadly ironic, much reliance on religious institutions may be attributed partly to the fact that religion often serves as succor to the helpless.

The Zaccheus Onumba Dibiaezue Memorial Libraries (ZODML), an indigenous Non Governmental Organization (NGO), broke the record of becoming the first local NGO to donate reasonable collections to prison libraries in Nigeria. ${ }^{46}$ The ZODML began with the Ikoyi Prison with resources that could facilitate Digital Learning. Impressed by the success of the Ikoyi experience, once again, in 2016, resources at three correctional facilities in Nigeria were simultaneously opened at Kirikiri Maximum Security, Medium Security, and Badagry prisons on April 17, 2016. No doubt commendable, ZODML's trail blazing is commendable, but this is only the beginning. Other NGOs and well-meaning individuals should also join to support the establishment of prison law libraries. The NGO also opened prison libraries in Nnewi and Ekwulobia prisons on October 4, 2017.47

${ }^{36}$ Rule 40 United Nations Standard Minimal Rules for the Treatment of Prisoners (1955).

${ }^{37}$ The Charter for the Readers (1994) published by UNESCO was developed by the International Book Committee and the International Publishers Associations.

${ }^{38}$ Education is one of the socio-economic rights that Nigerians are entitled to. However, at the moment, socio-economic rights are seen as non-justiciable rights.

${ }^{39}$ Although socio-economic rights on the face of it are non-justiciable, the Courts have held onto the spirit of judicial activism, in the form of Abacha V. Fawehinmi, who ensured that socio-economic rights contained in the African Charter Rights are enforceable in Nigeria.

${ }^{40}$ A visit to Nigerian prisons will show clearly that there are scarce books and other instructional materials for the inmates to read even though the government makes provision for reading chairs and carrels in some prisons. Meanwhile, the furniture so provided may not serve the intended purpose since inmates do not ordinarily have permission to bring-in reading materials into the prison.

${ }^{41}$ Ibid, Omagbemi.

${ }^{42}$ Omagbemi, C. O. \& Odunewu, A. (2015) “An Appraisal of Library Services to Prison Inmates in Nigeria," Samaru Journal of Information Studies, vol. 7, no. 2 (2007).

${ }^{43}$ The rule was adopted by the First United Nations Congress on the Prevention of Crime and the Treatment of Offenders, held at Geneva in 1955, and approved by the Economic. and Social Council through its resolutions 663 C (XXIV) of July 31, 1957 and 2076 (LXII) in 1977.

${ }^{44}$ The 11 percent statistics may not be a true reflection of how the prison library is used because they are so poorly equipped to provide effective services to inmates.

${ }^{45}$ Sambo, A., Usman, S. \& Rabiu, N. (2017) "Prisoner and their information needs: Prison libraries overview," Library Philosophy and Practice (e-journal), 1467.

46 Alabere, R. (2016) "The Commissioning of Prison Libraries in Lagos." Zaccheus Onumba Dibiaezue Memorial Libraries, https://zodml.org/blog/commissioning-prison-libraries-lagos\#.Wj_Ww1XwbIU.

${ }^{47}$ Egenuka, E. (2017) ZODML Commissions Prison Libraries in Nnewi and Ekwulobia, Zaccheus Onumba Dibiaezue Memorial Libraries. https://zodml.org/blog/zodml-commissions-prison-libraries-nnewi-and-ekwulobia\#.Wj_gzlXwbIU. 


\section{Lessons from the United STATES}

The United States of America is crucial to Nigeria because of the connection that exists between the two nations, owing to the fact that Nigeria currently fashions her democratic experience after the United States. ${ }^{48}$ About 2,200,000 inmates are incarcerated in the United States. ${ }^{49}$ As a result of this large population, we shall compare a case study of the United States of America vis-à-vis the Nigerian situation. This is important because the overriding philosophy behind Nigeria's Administration of Criminal Justice System is now fashioned alongside the American model, which places a high premium on a corrective system that is reformatory and rehabilitating rather than a punitive system that ended up producing more hardened criminals who are potential terrorists, rapists, and armed robbers. It is when this feat is achieved in Nigeria that we can begin to examine if Nigerian prison systems are at all positioned on the path to achieving success or not.

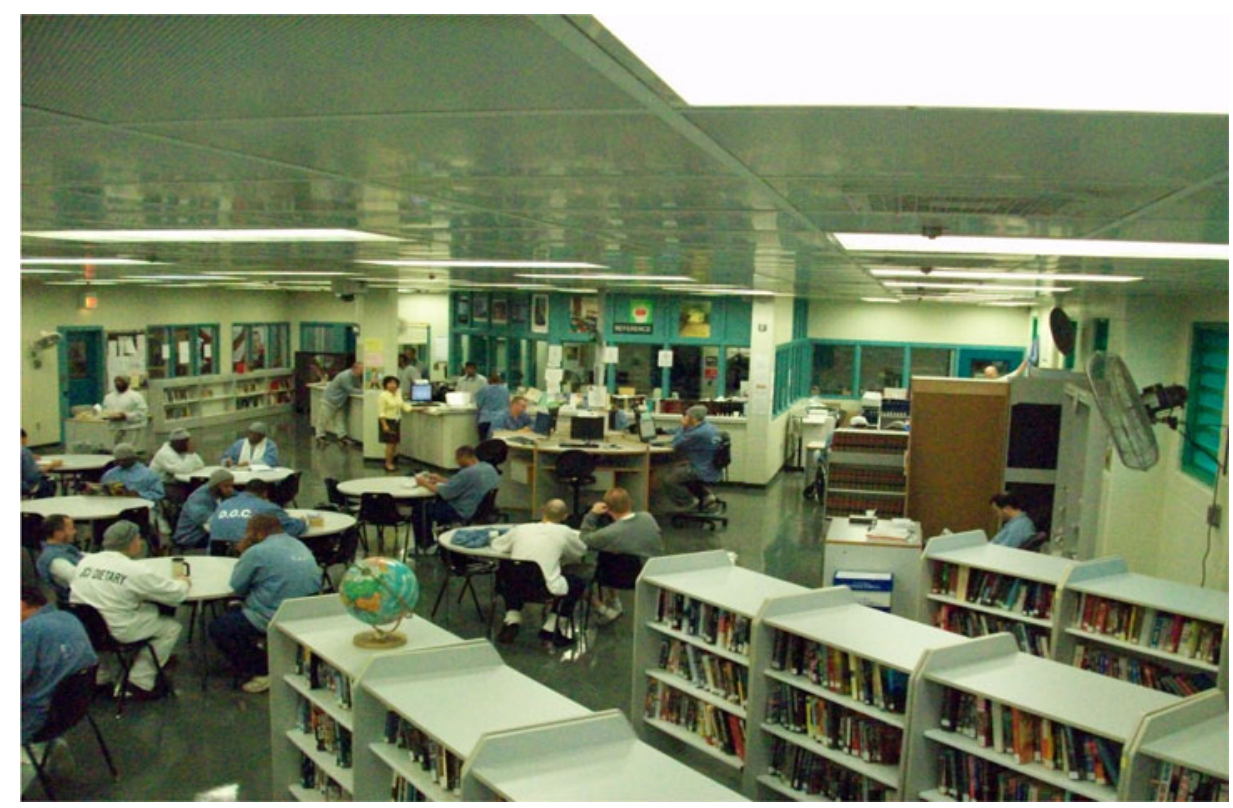

Picture of a typical prison library in the United States, Courtesy of Shea Alex (2017) ${ }^{50}$

Like many other developed countries, the United States has evolved a robust prison system, which is essentially reformatory rather than a somewhat punitive arrangement where inmates are perceived as individuals who should be isolated and severely punished for their misdeeds. The prison library is one of the special features of the prison where inmates are provided with life-changing literatures in different subject areas.

\section{The Kayuga Correctional Prisons Experience}

The Kayuga Correctional Facility is a United States prison facility that caters for the welfare of the inmates. The prison has two libraries. One is a general library and the other is a prison law library. The prison acquires only resources considered to be safe enough for inmates to read. To be able to use the libraries, intending users are

${ }^{48}$ Nigeria's adoption of the American-styled Presidential system of government began in 1979 when Alhaji Shehu Shagari won the Presidential election. Although truncated through the military junta, which led to the emergence of General Muhammadu Behari, who incidentally is Nigeria's current democratically elected President.

${ }^{49}$ Wagner, P. \& Sawyer, W. (2018), “Mass Incarceration: The Whole Pie 2018," Prison Policy Initiative. Retrieved from https://www.prisonpolicy.org/reports/pie2018.html, July 8, 2018.

50 Shea, A. (2017) “Banning black liberation: Michigan prisoners are barred from reading Frantz Fanon," MOCKROCK, https://www.muckrock.com/news/archives/2017/aug/04/michigan-doc-fanon/. 
expected to signify intentions prior to the usage. Thereafter, they are provided with access to enjoy the information resources in the library.

The library employs trained inmates who have gone through a lengthy training program and examination to be able to staff the library. In order to discharge its services effectively, there is budgetary allocation from the Government for the management of prison libraries. Some specific NGOs also support the Government efforts in this regard.

Concerning the type of resources provided for inmates, Kayuga Correctional Facility provides customized off-line resources for the inmates such that they are provided with information resources in a manner that the prison's security architecture is not compromised, while at the same time guaranteeing unhindered access to information.

\section{Concerns Over Prison Libraries}

A major concern when it comes to the welfare of inmates globally is to ensure that texts provided for inmates to read are actually safe. To avoid any doubt, information relating to either or many of the subjects ranging from violence, riot, rebellion, crime, insurrection, insubordination, revenge, and taking of drugs is usually disallowed from the prions because of the tendency to instigate the inmates against constituted authorities or fellow inmates. In overcoming this, efforts are usually made to ensure that certain designated officers are appointed to review the documents to be provided to the prison libraries.

This is one of the reasons why the government should ensure that information resources provided have been vetted by government officials appointed for this purpose. The implication of exposing readers to all manners of information is that, such misguided information could spur insurrection, ${ }^{51}$ rebellion, delinquent behavior, ${ }^{52}$ attempted prison breaks, ${ }^{53}$ or regular violence against fellow inmates or constituted authorities. An NGO could specialize in compiling or generating the list of approved items; however, the government cannot afford to risk relinquishing the entire task of censorship to the NGOs and the organized private sector.

Another concern is the likelihood of inmates having unauthorized interaction with the outside world. ${ }^{54}$ As a result, access to information channels that could undermine this provision are usually challenged. Access to information on improved communication like the Internet is often disallowed in the prisons. It must be acknowledged that inmates are allowed access to central telephones under strict supervision of the prison officials. Inmates can also write and receive letters, but there must be ways to ascertain that what is communicated will not compromise the security of either the prison or the larger society. By implication, even though there is much reliance on the use of the Internet for modern research activity, this is understandably not allowed in prison libraries. It must be stated that information is now being brokered in a manner such that specific information needs are being met without compromising the security architecture.

\section{Need for Prison Law Library In Nigeria}

The prison law library is an arm of the prison library, solely devoted to the provision of access to legal information for inmates. At the moment, there is no such library in Nigeria that is devoted to such. Perhaps it is essential to chronicle the origin of the same kind of library in the United States.

Even though prison libraries have been in the United States since 1790,55 with the first State prison library in $1802,{ }^{56}$ suffice it to say that these libraries and the ones established subsequently, were more like general (prison)

${ }^{51}$ For example, a book that deals on the exploits of terrorist organizations like the Taliban or Al-Qaida should not be kept in the prison library as this could end up recruiting individuals who could join terrorist organizations upon release from prison.

${ }^{52}$ There have been accounts of some successful armed robbers in Nigeria who terrorized people. An autobiography/biography of such persons should not be kept in the prison library. However, an account of a repented armed robber like Pastor Kayode Williams, which underplayed armed robbery, but rather beamed light on the futility of such adventure could be permitted to the extent that the writing did not touch sensitive areas such as the strategy of operations and the possibility of overpowering law enforcement agents.

53 This must be guarded against because it has been a reoccurring issue in Nigerian prisons owning partly to their overcrowded nature. Fapounda (2016 and 2017), ibid.

${ }^{54}$ This is considered to be a dangerous act because such interaction could precipitate the onslaught of greater crime.

${ }^{55}$ Rubin, R. J. (1973) "U.S. prison library services and their theoretical bases." Occasional Papers, No. 110.

56 Rubin, ibid. 
libraries until the landmark judgment in Bounds $v$ Smith, ${ }^{57}$ decided on April 27, 1977, ${ }^{58}$ where the court held, inter alia, that prisons were mandated by law to provide access to people trained in law or law library collections if the constitutional requirement of meaningful access to the courts was to be met. ${ }^{59}$ Lewis $v$ Casey varied the decision in Bounds $v$ Smith, stating that inmates are require to show that they were unable to advance their legal rights due to lack of access to an adequate prison law library facility.

In Nigeria, the possibility of having a prison law library is at the moment not within reach. This is despite the importance of prison law libraries. The truth is that the government will also want to shy away from its responsibilities, claiming financial inadequacy just as in the case of Bounds. It is essential that there be sustained advocacy on the part of the Civil Societies and other relevant stakeholders to ensure that the government recognizes - and in fact, that it actually does make provisions for prison law libraries. If need be, there could be a suit lawsuit instituted on behalf of inmates. ${ }^{60}$ With over 70 percent of inmates as PATs, it is incumbent on a given prison's authority to provide access to prison law libraries.

\section{Components of Modern Law Library}

Some of the resources that are necessary in a typical prison law library include access to basic laws: the constitution, laws of the federation, laws of the respective states, ${ }^{61}$ and national rights-based instruments. Other legal resources are also necessary, such as up-to-date specific and general law ${ }^{62}$ reports, ${ }^{63}$ briefs of arguments, appellant briefs and other pleadings, and rules of the court.

The law library should have a comfortable space to conduct independent legal research. This will include carrels and tables, computers (without Internet access) and printers from which inmates can prepare and print documents when required.

There can be newsletters, like Wire from Amnesty International, and other periodicals. Citators and digests and other reference materials should be procured. Forms and precedents are essential as well, as are basic reference materials such as a dictionary and Roget's Thesaurus.

A trained law librarian should be employed by the Government to manage these libraries. It has been recommended that the personnel should be on the ratio of one staff to 500 inmates. ${ }^{64}$ The space should be roomy enough for occasional talks, like orientation and capacity building. Besides the administrative duties, storage and display areas provided in the library, the library space should be wide enough to provide for other essential services, like: ${ }^{65}$

- reference station with counter and storage cabinets;

- reference desk;

- library office;

- staff workroom for technical processing, computer equipment, shelves, cupboards, book carts, and tables;

- shelving for library materials (books, magazines, newspapers, audiovisual materials);

- display area for books and promotional materials;

- reading tables and chairs;

57340 US 817 (1977).

${ }^{58}$ In this case, the respondents were current inmates at the correctional facilities of the North Carolina Department of Correction. In their three hitherto separate applications, now consolidated before the District Court for the Eastern District of North Carolina, the respondents averred that they were denied access to courts in grave violation of their rights as enshrined in the 14th Amendment by the State's inability to provide access to legal research facilities. While granting the respondents prayers, the Court noted that the sole prison library was inadequate, neither was there any other facility to provide legal assistance to inmates.

59 518 US 343 (1996).

${ }^{60}$ The Nigerian lawsuit now recognizes public interest litigations.

${ }^{61}$ Laws of States are necessary because a person can be convicted by a State law, and yet incarcerated in another State prison. This is partly because the Nigerian prison system is managed by the Federal Government of Nigeria.

${ }^{62}$ General reports to specific law reports such as criminal law reports, human rights law reports, and so on.

${ }^{63}$ Law reports are essential because inmates do not have access to the Internet. Also, the report is the main way in which Court business can be accessed.

${ }^{64}$ Lehmann, V. \& Locke, J. (2005) ibid.

${ }^{65}$ Ibid. 
- listening area;

- computers for patron use;

- photocopier; and

- space for group activities.

\section{How Can Prison Law Libraries Enhance the Administration of Justice?}

As remarked on earlier, the essence of ACJA is to cure the defects in the extant laws. More fundamentally, where inmates have access to prison law libraries, the inmates would be in the position to appreciate the reason for judgments of the Court. Inmates would become more enlightened and able to contribute meaningfully to their litigation processes. This means that they would be in the right position to better assist their own lawyers. Also, there could be instances in which an enlightened inmate may disagree with the trial plan of his counsel and might even effect a change of counsel.

Like the situation in the United States where inmates are provided with court processes as well as opportunities to prepare court processes using precedents provided in Court, Nigerian inmates, particularly those whose cases are currently at trial or on appeal, would have an opportunity to be more meaningfully involved in the process. Inmates can better appreciate how decisions are made and can personally see where there is a miscarriage of justice. Some of the other possible benefits include:

- inmates are conscious of their fundamental rights and can meaningfully contribute to the process leading to the litigation;

- inmates are also exposed to higher sanctions that can be meted against wrong doers in the event that the inmates commit another offense when released;

- some of the inmates may elect to study law librarianship upon being released from prison. Some may even elect to study law right from the beginning of their incarceration;

- some inmates even help colleagues to prepare their documents;

- it helps to build confidence in the legal system;

- it is in furtherance of the pursuit of the right to be informed of the offense committed, as well as the right for representation.

\section{Conclusion: What Can Be Done In Nigeria}

To ensure that prison libraries can adequately provide life-changing resources for inmates, particularly for persons awaiting trial, I make the following recommendations:

1. There is a need for the enactment of a law that will provide inmates with access to functional prison libraries. The law should clearly stipulate, in unambiguous terms, what constitutes functional prison libraries. It has been suggested that the Prisons Act last reviewed in 1972 is archaic. We subscribe to this view as well. Regrettably, efforts made to review that Act through the Prisons Act Amendment Bill first presented before the National Assembly in 2001 is still with the National Assembly in 2017. Perhaps more important to this study is the need to ensure that the proposed amendment makes allowances for the proper functioning of standard prison libraries in Nigeria. Also, it is suggested that the bill should capture other areas as well. ${ }^{66}$

2. There should be a proper demonstration of political will on the part of decision makers in providing for the welfare of inmates in Nigeria. This will ensure that there is reasonable budgetary allocation to support the activities of prison libraries.

3. There are partnerships and networks among critical partners across Ministries, Departments, and Agencies (MDAs), professional bodies such as the Nigerian Bar Association (NBA), Nigerian Library Association (NBA), and relevant NGOs in forging enduring partnerships for effective delivery of information to inmates.

\footnotetext{
${ }^{66}$ Other areas requiring attention include: provisions for the qualification of persons to man prison libraries, funding for the library, and other critical functions.
} 
4. There is a dire need to have stronger coordination between the interventions of the few NGOs who work to provide reading resources for the incarcerated in Nigeria. This is to ensure that these organizations do not work at cross-purposes. Having a forum for interaction will also provide a basis for support and experience sharing.

5. The curricula of library schools should be widened to include subjects on the management of prison libraries.

6. The NLA should have a professional unit for prison librarians. This will provide a platform for mentoring and networking among staff members of prison libraries in Nigeria.

7. Due to the risks associated with working in prisons, it is recommended that the Government provide incentives to persons who undertake to work in the prison libraries above what their contemporaries in other libraries earn. This would encourage persons to seek out career paths in this area.

8. Donor agencies, NGOs, funders, and local organizations should team up to support the efforts of the government in this regard. 